\title{
Effect of red clover/timothy ratio on the protein feeding value and the quality of silage
}

\author{
LIISA SYRJÄLÄ-QVIST ${ }^{1}$, EEVA PEKKARINEN ${ }^{1}$, JOUKO SETÄLÄ ${ }^{1}$ and \\ TAPANI KANGASMÄKI ${ }^{2}$
}

1 Department of Animal Husbandry,

2 Department of Plant Husbandry, University of Helsinki, SF-00710 Helsinki

\begin{abstract}
Five silages having different proportions of red clover and timothy $(100 / 0$, $75 / 25,50 / 50,25 / 75$ and $0 / 100$ ) were preserved in five glass-fibre silos of $0.4 \mathrm{~m}^{3}$. Chopped red clover and timothy were mixed during ensiling and preserved with AIV II solution ( $80 \%$ formic acid and $2 \%$ orthophosphoric acid), applied at the rate of $6 \mathrm{l} / 1000 \mathrm{~kg}$ fresh material.

The timothy sward was fertilized with $100 \mathrm{~kg} \mathrm{~N} / \mathrm{ha}$ and the red clover with $15 \mathrm{~kg} \mathrm{~N} / \mathrm{ha}$. The dry matter content in red clover was $14.5 \%$ and in timothy $18.6 \%$, and the crude protein content of DM $22.9 \%$ and $11.5 \%$, respectively. True protein formed $75-76 \%$ of crude protein in both herbages and the proportion of watersoluble $\mathrm{N}$ in total $\mathrm{N}$ was $32 \%$ in red clover and $36 \%$ in timothy. The rumen degradability of protein during the first two hours was under $10 \%$ in both herbages; after 18 and 24 hours it was $76 \%$ and $87 \%$ in red clover, and $65 \%$ and $70 \%$ in timothy. In red clover the contents of lysine, methionine and cysteine were $5.7 \mathrm{~g}, 0.4 \mathrm{~g}$ and $0.9 \mathrm{~g} / 16 \mathrm{~g} \mathrm{~N}$, respectively, the corresponding values for timothy being $4.8 \mathrm{~g}, 0.7 \mathrm{~g}$ and $1.4 \mathrm{~g} / 16 \mathrm{~g} \mathrm{~N}$.
\end{abstract}

In red clover the content of water-soluble carbohydrates was $10.6 \%$ of DM and in timothy $16.5 \%$; the contents of plant acids were $6.7 \%$ and $3.5 \%$ of DM, respectively. Red clover contained $10.9 \mathrm{~g} \mathrm{Ca} / \mathrm{kg} \mathrm{DM}$ and timothy $3.1 \mathrm{~g} \mathrm{Ca}$. The total amount of inorganic constituents was also higher in red clover than in timothy.

Although the chemical composition of red clover was less suitable for ensiling than the composition of timothy, the quality of all the silages was good. During ensiling the decrease in the proportion of true protein in crude protein and the increase in the proportion of watersoluble $\mathrm{N}$ in total $\mathrm{N}$ were smaller in red clover than in timothy silage. These changes were reflected in the ruminal protein degradation, which seemed to be slower when they were small. The amino acid profile of the protein did not alter during ensiling.

The ensiling losses were higher in the silages containing red clover than in the timothy silage. This conserned especially the effluent losses and surface spoilage of the feed.

Index words: red clover, timothy, protein quality, silage 


\section{Introduction}

Like the other legumes, red clover is an important food plant because of its nitrogenfixing properties and its relatively high content of protein. Until recently, it has been regarded as less suitable for ensiling than, for instance, the meadow grasses as clostridia have very often predominated during its fermentation, leading to poor quality silage. The reason for this has been thought to lie in the chemical composition of the legumes.

Since sugars are of central importance in the fermentation of silage, the low sugar content of the legume raw material makes the successful preparation of silage more difficult. The buffering properties of protein and especially organic acids are also a problem, since the high levels of these constituents in legumes interfere with the reduction in the $\mathrm{pH}$ of the fodder and increase the likelihood of undersirable fermentation. More recently, the disadvantages of legumes in terms of ensiling characteristics have been overcome by pretreatments such as chopping, crushing and wilting, and by the use of preservatives.

The purpose of this study was to investigate the quality and nutritive value of silages prepared from red clover (Trifolium pratense) and timothy (Phleum pratense) in different proportions. Special attention has been paid to the protein quality of both the silage raw material and the silages, and to the losses during ensiling.

\section{Experimental procedures}

The material for the experiments was from the first cutting ot the growing season in 1982. The red clover was from first-year and the timothy from second-year sward. Nitrogen fertilizer had been applied in spring at rates of $15 \mathrm{~kg} \mathrm{~N} / \mathrm{ha}$ on the red clover sward and $100 \mathrm{~kg} \mathrm{~N} /$ ha on the timothy sward. The harvesting time was 18 June, when the red clover had started budding and the ears of timothy were near emergence or just formed.
The yields per hectare were determined for red clover and timothy during harvesting.

Five silages with different proportions of red clover and timothy were preserved in five glass-fibre silos of $0.4 \mathrm{~m}^{3}$. Chopped red clover and timothy were mixed during ensiling using the following proportions:

Silage 1: $100 \%$ red clover

Silage 2: $75 \%$ red clover and $25 \%$ timothy Silage 3: $50 \%$ red clover and $50 \%$ timothy Silage 4: $25 \%$ red clover and $75 \%$ timothy Silage 5: $100 \%$ timothy

AIV II solution $(80 \%$ formic acid and $2 \%$ orthophosphoric acid) was used as preservative, being applied as the silos were filled, at rates of $6 \mathrm{l} / 1000 \mathrm{~kg}$ fresh material.

Samples of the raw materials and different silages were subjected to the standard feed analyses and analysed for the properties used as criteria of the quality of silage, especially those of silage protein. The quality of the silage $(\mathrm{pH}$, water-soluble carbohydrates, lactic acid, volatile fatty acids, $\mathrm{NH}_{3}-\mathrm{N}$ and watersoluble $\mathrm{N}$ ) was determined as described by Syrjàla (1972). The in vitro digestibility was determined by the method of Tilley and Terry (1963) and the ruminal degradability of the feeds on grass silage diet by the nylon bag technique (MehreZ and ØrSKOv 1977) as described by SETÄLÄ (1983). The amino acids were determined with a Technicon amino acid analyzer, and plant acids by the method of Salo and Kotilainen (1969).

\section{Results and discussion}

Comparison of red clover and timothy herbages

The red clover sward gave higher yields than the timothy, the dry matter yield of red clover averaging $4970 \mathrm{~g} / \mathrm{ha}$ and that of timothy $3700 \mathrm{~kg} / \mathrm{ha}$. The crude protein yield of red clover was about 2.5 times as high as that of timothy, the values being 1138 and $426 \mathrm{~kg} / \mathrm{ha}$, respectively. This was at least partly caused by the unusually low crude protein content of timothy, $11.5 \%$ of dry 
matter (DM), as opposed to $22.9 \%$ of DM in red clover. On the other hand, the dry matter and crude fibre contents of red clover were lower than those of timothy (Table 1). Before harvesting the weather was unusually cold and rainy and it seemed that especially the growth of timothy had suffered from this. Cold weather has earlier been observed to decrease the protein content of grasses (SAlo et al. 1975).

Although the crude protein content differed, the criteria of the protein quality were similar in red clover and timothy. The proportion of true protein in crude protein was $75-76 \%$ in both herbages (Table 2 ). The proportion of water-soluble nitrogen in total nitrogen was somewhat lower in red clover than in timothy, $32 \%$ vs. $36 \%$. The rumen degradability of the protein during the first two hours was low in both herbages, under $10 \%$ (Fig. 1). After 18 and 24 hours, however, it was $76 \%$ and $87 \%$ in red clover, as opposed to $65 \%$ and $70 \%$ in timothy.

The amino acid contents of red clover and timothy protein did not differ greatly (Fig. 2). In red clover, the content of lysine was slightly higher than in timothy, $5.7 \mathrm{~g}$ vs. $4.8 \mathrm{~g} / 16 \mathrm{~g} \mathrm{~N}$, whereas timothy had more sulphur-containing amino acids than red clover. The content of methionine in timothy was $0.7 \mathrm{~g} / 16 \mathrm{~g} \mathrm{~N}$ and that of cysteine $1.4 \mathrm{~g} /$ $16 \mathrm{~g} \mathrm{~N}$. The corresponding values in red clover were $0.4 \mathrm{~g}$ and $0.9 \mathrm{~g} / 16 \mathrm{~g} \mathrm{~N}$. These differences in the amino acid composition agree with those reported between legumes and grasses, e.g. red clover and Italian ryegrass (EPPENDORFER 1977).

The content of water-soluble carbohydrates (sugars) in timothy was $16.5 \%$ of DM and in red clover $10.6 \%$. The amount of plant acids describes the total acidity of herbage. Expressed as the content of malic acid, it was nearly twice as high in red clover as in timothy (Table 2). In this experiment, the amounts of plant acids were slightly lower than those found by SALO and KotrLAINEN (1969), but the differences between red clover and timothy were similar.

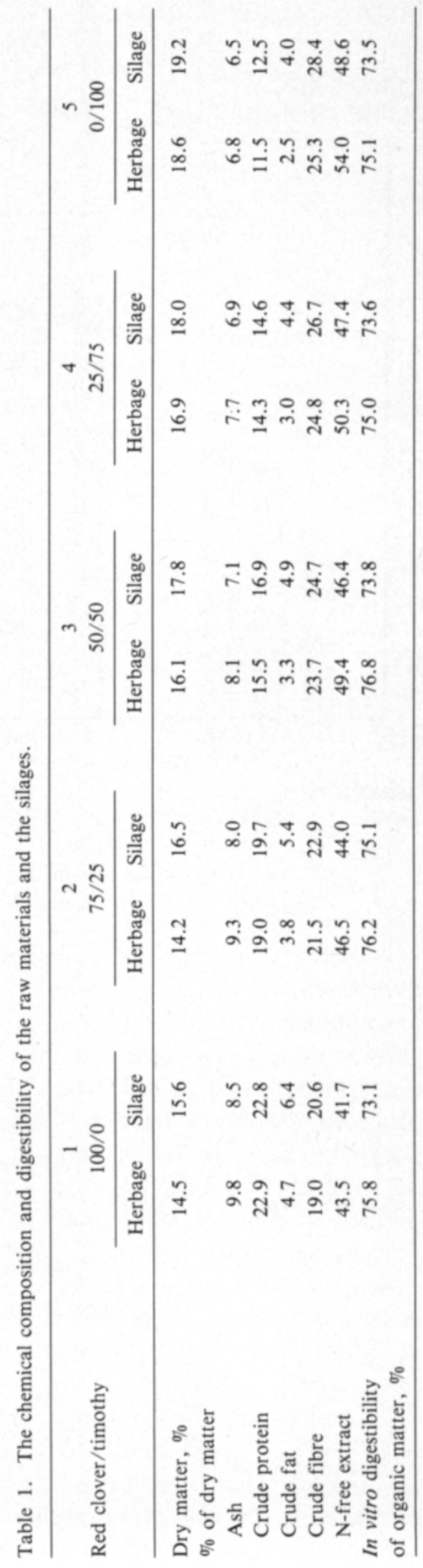




\section{Degradability \\ of crude protein, $\%$}

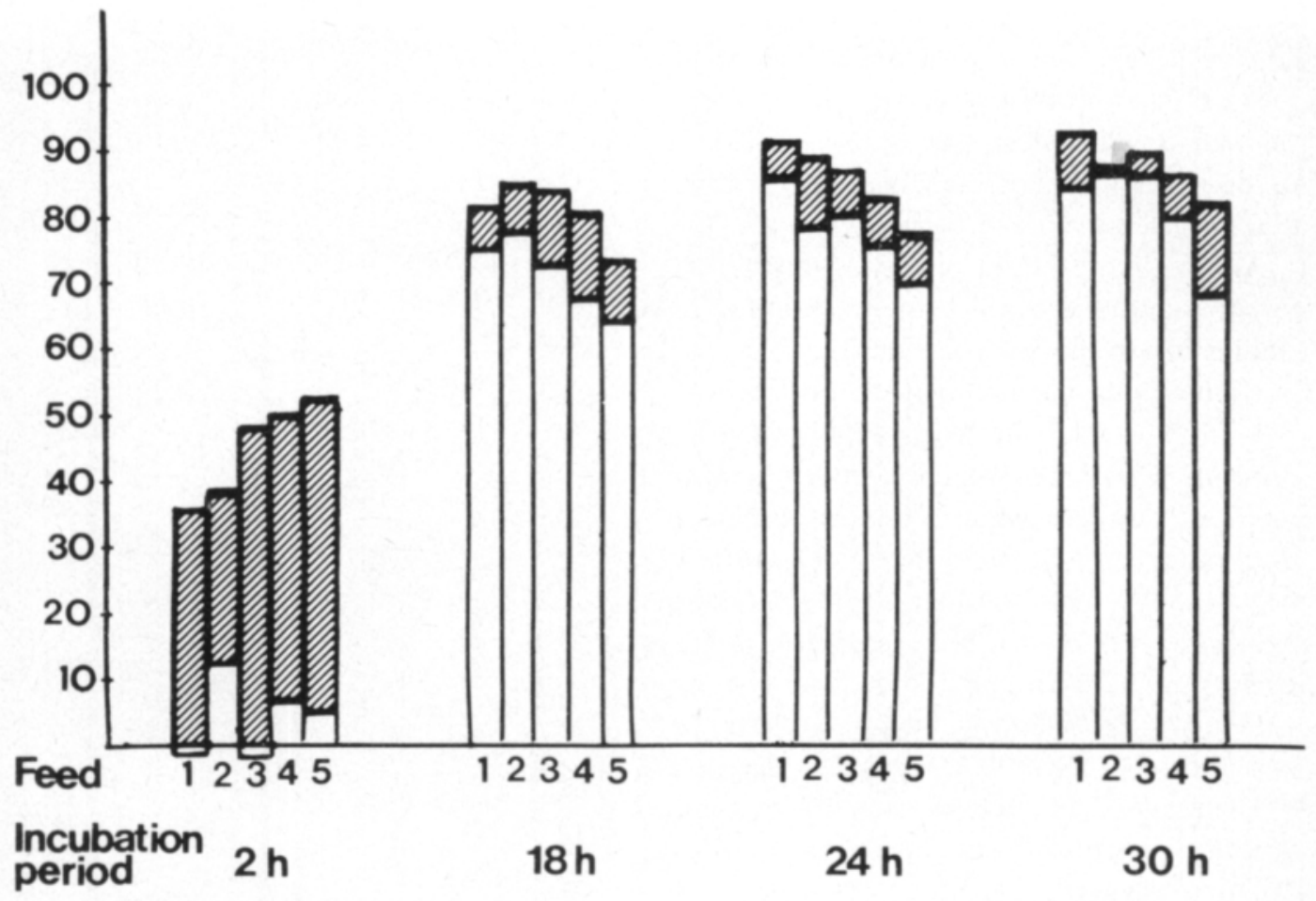

Fig. 1. The rumen degradability of the protein of the raw materials and the silages. $(1=100 \%$ clover, $2=75 \%$ clover and $25 \%$ timothy, $3=50 \%$ clover and $50 \%$ timothy, $4=25 \%$ clover and $75 \%$ timothy, $5=100 \%$ timothy).

The total amount of inorganic substances was higher in red clover than in timothy (Table 1). Red clover contained more than three times as much $\mathrm{Ca}$ as timothy, $10.9 \mathrm{~g}$ vs. $3.1 \mathrm{~g} / \mathrm{kg}$ DM (Table 3). The amounts of P, $\mathrm{Mg}, \mathrm{K}, \mathrm{Fe}, \mathrm{Zn}$ and $\mathrm{Cu}$ were also higher in red clover than in timothy, but timothy contained more $\mathrm{Na}$ and $\mathrm{Mn}$ than red clover. The differences in the mineral contents of red clover and timothy were similar to those found earlier (SAlo et al. 1975, SAlo et al. 1982).

\section{Changes during ensiling}

As regards its chemical composition, red clover has been found less suitable for ensi- ling than timothy (McDonald 1981). This concerned especially the contents of crude protein, mineral substances and plant acids, which were higher in red clover, and the content of watersoluble carbohydrates, which was lower in red clover than in timothy. In this study the ratio of sugars to protein in red clover was 0.5 and in timothy 1.4 , these levels being the same as in earlier studies (SAlo et al. 1975, SyrJälä-Qvist 1982).

The quality of all the silages was good (Table 2), if account is not taken of surface spoilage of the feed in some silos, especially in the silos containing more clover. The fermentation level in all the silages was low, as is evident from the high content of sugars and low content of volatile fatty acids. The 

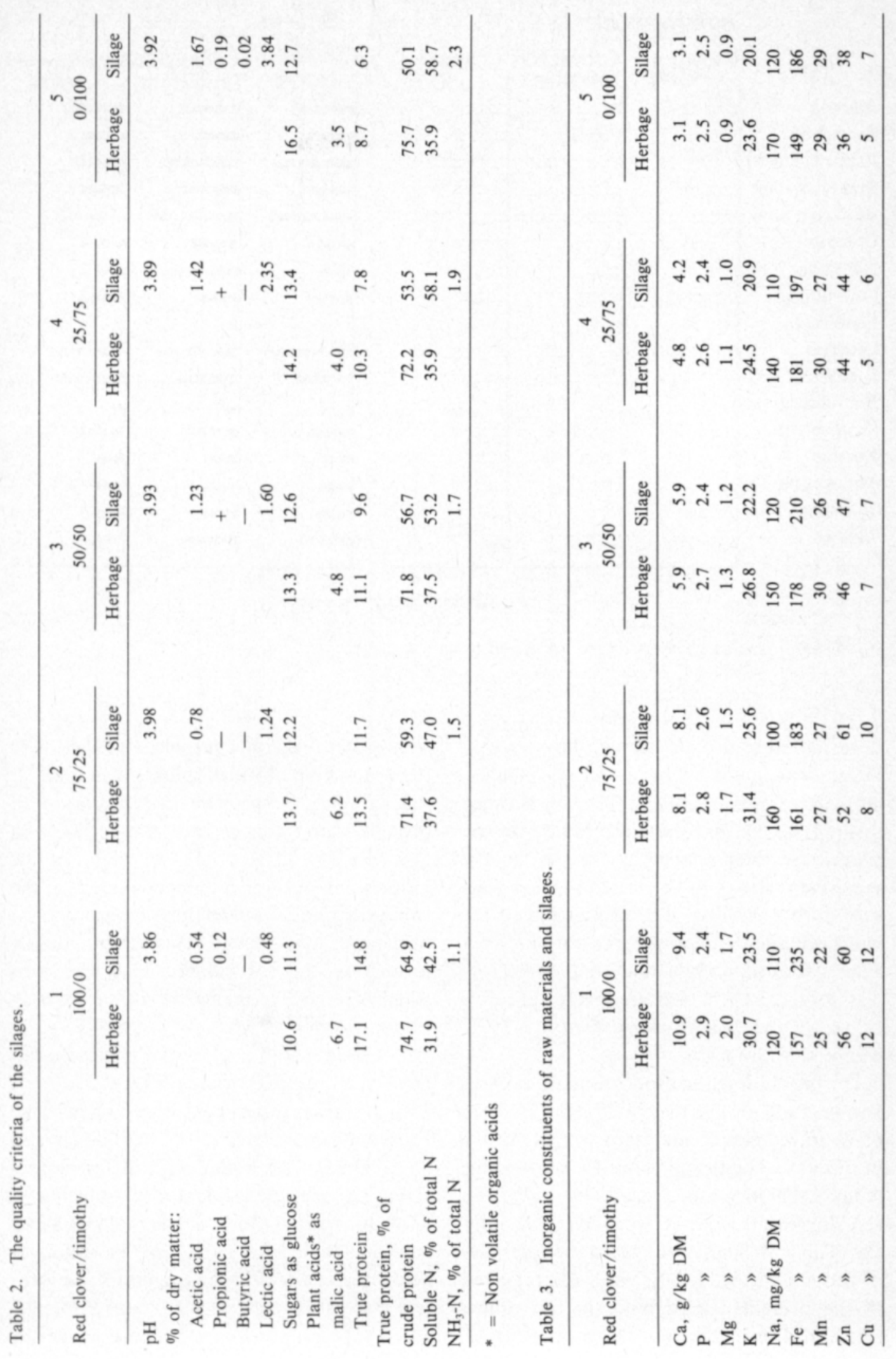
Raw materials

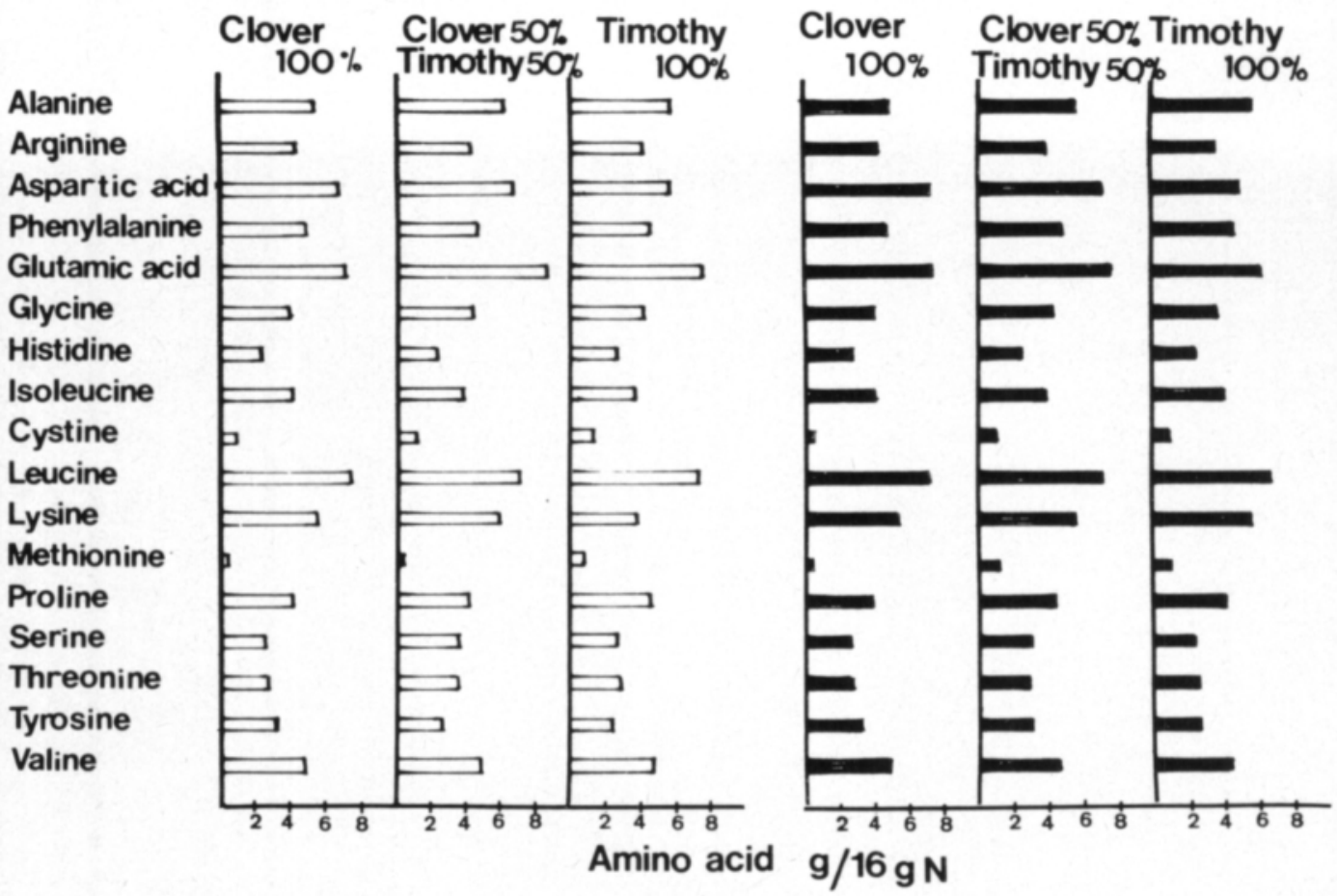

Fig. 2. The amino acid contents of the raw materials and the silages.

degradation of protein during silage fermentation was quite slight in all the silages, although there were some differences between them. It seems that the more red clover the silage raw material contained, the smaller were the changes in the crude protein fraction during ensiling. The proportion of the water-soluble $\mathrm{N}$ in total $\mathrm{N}$ in the different silages was $42-59 \%$ and that of $\mathrm{NH}_{3}-\mathrm{N}$ was $1.1-2.3 \%$, which are levels indicative of very good quality silage (SYRJÄLÄ 1972, McDonald 1981).

During ensiling the proportion of true protein in crude protein decreased from $75 \%$ to $65 \%$ in red clover and from $76 \%$ to $50 \%$ in timothy. The proportion of water-soluble $\mathrm{N}$ in total $\mathrm{N}$ increased from $32 \%$ to $43 \%$ in red clover and from $36 \%$ to $59 \%$ in timothy (Table 2). These changes in the solubility of protein during ensiling were also reflected in the protein degradability in the rumen (Fig. 1). The higher was the proportion of true protein in crude protein and the lower the proportion of water-soluble $\mathrm{N}$ in total $\mathrm{N}$, the slower was the rumen degradation of protein. After longer incubation times, in this case 24 and 30 hours, the effect of the lower solubility was no longer evident in the rumen degradability. In those longer incubation times, the rumen degradability of the protein of the red clover silage was even somewhat greater than that of the timothy silage.

The amino acid profile of the protein did not change during ensiling (Fig. 2).

In an earlier experiment, in which herbage containing red clover $(50 \%$ red clover and $50 \%$ grass) was ensiled with different preservatives (formic acid, Viher solution = $55 \%$ formalin $+30 \%$ acetic acid and Viher acid $=25 \%$ formalin $+60 \%$ sulphuric acid), the changes in the quality of the protein were also small (Syrjälä and Poikonen 1978). The proportion of true protein in the 
crude protein decreased from $83 \%$ in the raw material to $69-74 \%$ in the silages and the proportion of water-soluble $\mathrm{N}$ in total $\mathrm{N}$ ranged from 34 to $40 \%$ in the different silages. As even in a good quality silage a great proportion of the protein is degraded rather rapidly in the rumen (SALO et al. 1982), the slower rumen degradation of the protein in silages with red clover would favour efficient utilization of protein.

The $\mathrm{pH}$ values were low in all the silages, being under 4 . One reason for this may be the rather large amounts of silage additive used for all the silages, 6 I AIV II solution/ $1000 \mathrm{~kg}$ fresh feed. In practice the amounts of additives recommended for grasses are about $4 \mathrm{l}$ and for leguminous crops 5-6 l/ $1000 \mathrm{~kg}$. These high amounts of additive may also be one reason for the low fermentation level of the silages in this experiment.

The in vitro digestibility of organic matter was rather high and at the same level in red clover and timothy. It varied from $75.0 \%$ to $75.8 \%$ in the raw materials and from $73.1 \%$ to $75.1 \%$ in the silages (Table 1).

The palatability of the silages with red clover was good, the average voluntary intake of DM by sheep being $2.3 \mathrm{~kg} / 100 \mathrm{~kg}$ liveweight.

\section{Ensiling losses}

In this experiment the fermentation losses were small for all silages, under $4 \%$ of the fresh herbage. In contrast, the effluent losses formed a large part of the ensiling losses. The harvesting day was dry, though cloudy, but the preceding days had been very rainy. The dry matter contents of the herbages were low, $14.5 \%$ in red clover and $18.6 \%$ in timothy. The losses of nutrients in the effluent were considerable, especially in the silages containing more clover (Table 4).

The effluent losses chiefly depend on the dry matter content of the herbage (McDoNALD 1981). In an earlier experiment the dry matter content of the raw material (50\% red clover and $50 \%$ grass) was $19.6 \%$ and the effluent losses averaged only $7.2 \%$ of the fresh herbage and the dry matter losses in the effluent averaged $2.3 \%$ (PoIKONEN 1979). The dry matter content of red clover is usually lower than that of grasses, so that the effluent losses may easily be greater in silages with red clover. McDonald et al. (1965) regarded the relatively low dry matter content and high effluent losses as a disadvantage in ensiling red clover.

There was some surface spoilage in all the silos, but especially in the silages containing more red clover, which showed that red clover silages are more easily spoiled by oxidation than timothy silages. It would therefore be better to ensile silages with red clover in tower silos, than in stack silos.

The mineral losses of silage mainly occur in the effluent losses (SALO and SORMUNEN 1976). The content of different minerals was clearly higher in the dry matter of the effluents than in the dry matter of the raw materials or the silages (Tables 3 and 5). As the ratio of clover in the silage increased the mineral losses in the effluent also rose (Table 5).

Table 4. The effluent losses, $\%$ of the ensiled amounts.

\begin{tabular}{lrrrrr}
\hline & 1 & 2 & 3 & \multicolumn{1}{c}{4} & 5 \\
Clover/timothy & $100 / 0$ & $75 / 25$ & $50 / 50$ & $25 / 75$ & $0 / 100$ \\
\hline Total & 30.4 & 32.9 & 26.6 & 19.2 & 12.4 \\
DM & 10.3 & 12.0 & 9.0 & 6.8 & 4.3 \\
Organic matter & 8.9 & 10.4 & 7.7 & 5.8 & 3.9 \\
Ash & 22.3 & 28.1 & 23.2 & 8.3 & 11.3 \\
Crude protein & 9.1 & 10.0 & 8.6 & 5.9 & 5.2 \\
Sugars as glucose & 31.4 & 35.6 & 30.2 & 23.2 & 15.5 \\
\hline
\end{tabular}


Table 5. The mineral content of the effluent and the mineral losses.

\begin{tabular}{|c|c|c|c|c|c|}
\hline \multirow[b]{2}{*}{ Clover/timothy } & 1 & 2 & 3 & 4 & 5 \\
\hline & $100 / 0$ & $75 / 25$ & $50 / 50$ & $25 / 75$ & $0 / 100$ \\
\hline \multicolumn{6}{|l|}{ In the effluent: } \\
\hline $\mathrm{Ca} \mathrm{g} / \mathrm{kg} \mathrm{DM}$ & 17.0 & 15.6 & 13.4 & 11.9 & 8.9 \\
\hline P $\quad "$ & 5.8 & 5.8 & 6.2 & 6.3 & 5.9 \\
\hline $\mathrm{Mg}$ & 4.7 & 3.9 & 3.4 & 3.1 & 2.6 \\
\hline $\mathrm{Na}$ & 2.8 & 2.1 & 2.1 & 1.8 & 1.7 \\
\hline K $\quad "$ & 83.3 & 84.0 & 83.1 & 91.1 & 76.6 \\
\hline $\mathrm{Fe} \mathrm{mg} / \mathrm{kg} \mathrm{DM}$ & 244 & 191 & 188 & 229 & 210 \\
\hline Mn $\quad "$ & 62 & 64 & 79 & 91 & 91 \\
\hline \multirow{2}{*}{$\begin{array}{ll}\mathrm{Zn} & \prime \\
\mathrm{Cu} & \cdots\end{array}$} & 161 & 144 & 160 & 262 & 127 \\
\hline & 16 & 14 & 14 & 13 & 9 \\
\hline \multicolumn{6}{|c|}{$\begin{array}{l}\text { The mineral losses, } \% \\
\text { of contents of herbage }\end{array}$} \\
\hline $\mathrm{Ca}$ & 16.0 & 23.0 & 20.2 & 16.5 & 12.6 \\
\hline $\mathrm{P}$ & 20.5 & 24.6 & 20.3 & 16.3 & 10.5 \\
\hline $\mathrm{Mg}$ & 23.7 & 28.1 & 22.6 & 19.3 & 12.4 \\
\hline $\mathrm{Na}$ & - & - & - & - & - \\
\hline K & 27.8 & 32.1 & 27.8 & 24.7 & 14.3 \\
\hline $\mathrm{Fe}$ & 15.9 & 14.3 & 9.5 & 8.5 & 6.2 \\
\hline $\mathrm{Mn}$ & 25.5 & 28.3 & 23.3 & 20.1 & 13.7 \\
\hline $\mathrm{Zn}$ & 29.5 & 33.3 & 31.3 & 39.6 & 15.4 \\
\hline $\mathrm{Cu}$ & 14.3 & 20.4 & 19.3 & 15.7 & 7.2 \\
\hline
\end{tabular}

\section{References}

EPPEndorfer, W.H. 1977. Amino acid composition and nutritional value of Italian ryegrass, red clover and lucerne as influenced by application and content of nitrogen. J.Sci.Fd.Agric. 28: 607-614.

Mcdonald, P. 1981. The Biochemistry of Silage. Chichester, John Wiley and Sons Ltd. 226 p.

Mcdonald, P., Stirling, A.C., Henderson, A.R. \& Whittenbury, R. 1965. Fermentation studies on red clover. J.Sci.Fd.Agric. 16: 549-557.

Mehrez, A.Z. \& Ørskov, E.R. 1977. A study of the artificial fibre bag technique for determining the digestibility of feeds in the rumen. J.Agric.Sci., Camb. 88 : 645-650.

Poikonen, H. 1979. Puna-apila săilörehun raaka-aineena. Laudatur-työ. 88 p. Helsingin yliopisto, kotieläintieteen laitos.

Salo, M.-L. \& Kotilainen, K. 1969. Determination of free and combined plant acids. J.Sci.Agric.Soc.Finl. 41: 277-289.

Salo, M.-L., Nykānen, A. \& Sormunen, R. 1975. Nurmikasvien koostumus, pepsiini- $\mathrm{HCl}$-liukoisuus ja in vitro -sulavuus eri kasvuasteilla. J.Sci.Agric.Soc.Finl. 47: 480-490.

SAlo, M.-L. \& Sormunen, R. 1976. Nurmisäilörehukokeita maatilasiiloissa. 2. Kivennäispitoisuuden muu- tokset ja säilöntătappiot. J.Sci.Agric.Soc.Finl. 48: $128-137$.

Salo, M.-L., TuOri, M. \& KIISKInen, T. 1982. Rehutaulukot ja ruokintanormit. p. 60. Helsinki 1982.

Setälä, J. 1983. The nylon bag technique in the determination of ruminal feed protein degradation. J.Sci.Agric.Soc.Finl. 55: 1-78.

Syrjà.A., L. 1972. Effects of different sucrose, starch and cellulose supplements on the utilization of grass silage by ruminants. Ann.Agr.Fenn. 11: 199-276.

Syrjalä, L. \& Poikonen, H. 1978. Puna-apila säilörehun raaka-aineena. Koetoiminta ja kảytăntö 6. 6. 1978: 24.

SyrJálà.Qvist, L. 1982. Palkokasvien säilöntä ja kảyttö rehuna. Preservation of legumes for use as fodder. The Second National Symposium on Biological Nitrogen Fixation, Helsinki $8^{\text {th }}-10^{\text {th }}$ of June. The Finnish national fund for research and development. Nitrogen project. Report 1: 99-104.

Tilley, J.M.A. \& Terry, R.A. 1963. A two-stage technique for the in vitro -digestion of forage crops. J.Br.Grassld.Soc. 18: 104-111.

Ms received July 10, 1984 


\section{SELOSTUS}

\section{Puna-apila/timotei-suhteen vaikutus valkuaisen ruokinta-arvoon ja säilörehun laatuun}

\section{Liisa Syrjälä-Qvist ${ }^{1}$, Eeva Pekkarinen' Jouko Setälä' ja Tapani Kangasmäki ${ }^{2}$}

1 Kotieläintieteen laitos, ${ }^{2}$ Kasvinviljelytieteen laitos, Helsingin yliopisto, 00710 Helsinki 71

Puna-apilasta ja timoteista valmistettiin eri suhteissa $(100 / 0,75 / 25,50 / 50,25 / 75$ ja $0 / 100)$ säilörehut $0.4 \mathrm{~m}^{3}: \mathrm{n}$ lasikuitusiiloihin. Säilöntäaineena oli AIV II liuos ja sită käytettiin $6 \mathrm{l} / 1000 \mathrm{~kg}$ tuoretta rehua.

Koerehut olivat kevătsatoa. Timotei oli saanut typpeă $100 \mathrm{~kg} / \mathrm{ha}$ ja apila $15 \mathrm{~kg} / \mathrm{ha}$. Puna-apilan kuiva-ainesato oli $4970 \mathrm{~kg} / \mathrm{ha}$ ja raakavalkuaissato $1138 \mathrm{~kg} / \mathrm{ha}$. Timotein vastaavat sadot olivat $3700 \mathrm{~kg}$ ja $426 \mathrm{~kg} / \mathrm{ha}$. Kuiva-ainetta oli apilassa $14.5 \%$ ja timoteissa $18.6 \%$ ja raakavalkuaispitoisuus edellisessä $22.9 \%$ ja jălkimmäisessă $11.5 \%$ kuiva-aineesta.

Puhdasvalkuaisen osuus raakavalkuaisesta oli molemmissa kasveissa lăhes sama, 75-76 \%. Liukoisen typen osuus kokonaistypestă oli apilassa $32 \%$ ja timoteissa $36 \%$. Valkuaisen pötsihajoavuus oli kahden ensimmäisen tunnin aikana molemmissa alle $10 \%$, apilassa 18 ja 24 tunnin jălkeen $76 \%$ ja $87 \%$, timoteissa vastaavina aikoina $65 \%$ ja $70 \%$. Puna-apila sisälsi enemmän lysiiniä kuin timotei $(5.7 \mathrm{~g}$ ja $4.8 \mathrm{~g} / 16 \mathrm{~g} \mathrm{~N})$, mutta vähemmăn rikkipitoisia aminohappoja (apilassa metionii- nia $0.4 \mathrm{~g}$ ja kystiiniă $0.9 \mathrm{~g} / 16 \mathrm{~g} \mathrm{~N}$, timoteissa vastaavat luvut $0.7 \mathrm{~g}$ ja $1.4 \mathrm{~g} / 16 \mathrm{~g} \mathrm{~N})$.

Sokereita oli apilassa $10.6 \%$ ja timoteissa $16.5 \%$ kuiva-aineesta sekä kasvihappoja vastaavasti $6.7 \%$ ja $3.5 \%$. Puna-apila sisălsi epăorgaanisia aineita enemmăn kuin timotei, varsinkin kalsiumia (apilassa kalsiumia $10.9 \mathrm{~g}$, timoteissa $3.1 \mathrm{~g} / \mathrm{kg} \mathrm{ka)}$.

Vaikka apilan kemiallinen koostumus oli säilörehukäymisiă ajatellen epäedullisempi kuin timotein, olivat kaikki săilörehut laadultaan hyviä. Säilönnăn aikana puhdasvalkuaisen osuus raakavalkuaisesta laski ja liukoisen typen osuus kokonaistypestă lisảaantyi apilaa sisăltăvissă săilörehuissa văhemmăn kuin timoteisăilörehuissa. Erot heijastuivat myös raakavalkuaisen pötsihajoavuuteen, joka oli sită hitaampaa, mită pienemmiksi muutokset jäivăt.

Săilöntătappiot olivat puna-apilaa sisăltăvissă săilörehuissa suuremmat kuin timoteisăilörehuissa. Tämă koski varsinkin puristenestetappioita ja pintapilaantumista. 